\title{
The Role of the Traditional Crafts as Intangible Heritage on the Global Tourist Market
}

\author{
Marija Dragicevic Curkovic ${ }^{1, *}$ \\ ${ }^{1}$ University of Dubrovnik, Department of Economics and Business, Lapadska obala 7, 20000, \\ Dubrovnik, Croatia
}

\begin{abstract}
.
Research background: The results of the researches in the word show that traditional crafts play very important role in presenting the culture and traditions of any country and provide opportunities for employment with low capital investments. Dubrovnik traditional crafts have not been touristic valorized as well. That is why is relevant to analyse the role and development possibilites of Dubrovnik traditional crafts from international poin of view.

Purpose of the article: The aim of the paper was to analyse importance and types of traditional crafts as much as to explore the attitudes of local residents in the area of Dubrovnik towards the possibilities of developing new tourism products forms based on the traditional crafts.

Methods: For the purpose of the paper the secondary and primary data have been used. The empirical research has been conducted using the structured interview method. The sample has consisted of 48 employees. The respondents were residents, employed by companies in Dubrovnik. The results of primary and secondary researches have been considered together regarding the elements of cultural motivation.

Findings \& Value added: The local residents consider that traditional crafts could be important factor of sustainable development of tourist destinations Dubrovnik. There is an interest in "reviving" them and valorizing for tourism purposes, especially Konavle, Mljet and Coastal embroidery, Knitting, Stonemasonry and Sericulture. All traditional crafts had been currently positioned in the area of mediocre level of tourist valorization.
\end{abstract}

Keywords: traditional crafts; role; global market; tourism; Dubrovnik

JEL Classification: $L 8$

*Corresponding author: mdragicevic@unidu.hr 


\section{Introduction}

Many tourist destinations use cultural heritage as places for interpretation and education. [1]. According to Wang experience theory [2], clients feel authentic when they are involved in unusual activities in which they can express themselves freely or to achieve. Among the most important reasons for this is the recognition of cultural resources, which can play a significant role in the development of the local community and the influence on higher level of life quality such as to contribute to the creation of individual and collective identity of the community [3], and better promotion, understanding and survival of traditional crafts [4]. Ancient handicraft techniques in many societies across the world they still play an integral role in daily life. These products are unique and often personalized to each individual's taste and preference and they have been a source of livelihood, heritage, and creativity. They have also been a point of interaction and sharing of ideas. These traditional crafts are being marginalized due to urbanization and industrialization. Artisans are abandoning crafts in favor of more lucrative professions. There is imminent danger of traditional crafts becoming extinct [5]. The paper is focused on the meaning of traditional crafts at the international tourist market. The paper also explores the possibilities of "revival" of them in ACI Marine in the area of Komolac, Dubrovnik. In this regard, an empirical survey was conducted, using a structured interview method involving 48 respondents. Descriptive statistics were used when analysing the data.

\section{The importance of traditional crafts on the international market}

In the Convention for the Protection of World Cultural and Natural Heritage [6] the heritage is pragmatically defined as follows: "Cultural heritage refers to monuments, groups of buildings and sites that have historical, aesthetic, archaeological, scientific, ethnological and anthropological value". There are three main components of the Convention in defining cultural heritage: 1. monuments: works of architecture; monumental works in the field of sculpture and painting; elements or structures of an archaeological nature; drawings, caves and residences; combinations of features of exceptional universal value, historical, artistic or scientific; 2. group of buildings: groups of detached or related buildings which, due to their architecture, homogeneity or environmental position, possess exceptional universal value, historical, artistic or scientific; 3. localities: works of man or combined works of nature and man, and areas including archaeological sites of exceptional universal value, historical, artistic or scientific. The limitation of this definition is that it refers only to the material dimension of culture. The definition of intangible cultural heritage which becomes an integral part of the Convention has been accepted at the 32nd session of the UNESCO General Conference. Intangible cultural heritage referred to the things in the following domains: oral tradition, expression and language, stage art, social practice, rituals and ceremonies, knowledge and practice on nature and the universe and traditional crafts. Products that are fully hand-manufactured or with the help of tools in such a way that human labour and skills in relation to tools have priority in making products [7] fall into traditional crafts. Their role is to express culture in the way of life and also to have practical value [8].

India is one of the major exporter and supplier of handicrafts and gift products to the world market. The Indian handicrafts industry is highly labor intensive and decentralized, being spread all across the country in rural and urban areas. The sector is considered as the second largest employment-generating sector after agriculture with numerous artisans engaged in craft work on a part-time basis. The industry offers employment to over 6 million artisans, including a large number of women and people from the weaker sections 
of society. The present day handicraft tradition of India is a perfect example of assimilation between the traditional designs and modern techniques. The fast growing demand for Indian handicraft and gifts products have made this sector a full-fledged large scale organized industrythat is growing day by day. The most popular crafts, include metalware, earthenware, pottery, sculpting, woodwork, hand-printed textiles and scarves, embroidered and crocheted goods, shawls, zari products, stone carving and imitation jewelry. The present status of the sector in India owes much to the rich crafts history and tradition of the past. The growth of these industries is due to their ever-increasing demand and the popularity of Indian crafts in the domestic market and overseas. Gems and jewelry, carpet making, metalware, leather products, jute products etc. are some industriesare growing rapidly [9]. The increase in the production of handicrafts in India (continuous growth rate of $20 \%$ ), contributes to the promotion of culture and the employment of women, but also sets new requirements for innovative solutions that would facilitate the production of traditional products $[10,11]$.

Crafts tourism in India, has gained immense popularity and is quite valued by not only the domestic but also the foreign travelers from all parts of the world. For instance, Orissa occupies a prominent place among all the other states of India and its craftsmen are specialized in the production of exquisite hand-made trousseau sarees. Apart from Orissa, the craft show in Rajasthan is also very popular and is valued by the tourists who are the true appreciators of craft works. The handicraft shops in Rajasthan are huge in number and house a large number of incredible craft items such as antiques, pottery items, dhurries and carpets, fabrics, furniture and wood carving items, gesso works, jewelry and gemstones, leather ware, metal crafts, paintings, puppets, stone carvings. Moreover, the paintings and the hand-made royal furnishings found in the royal mansions and also in the shops are quite famous [12]The Channapatna toys are softwood toys locally manufactured in Channapatna town, Bangalore rural-district in India. These toys are usually made from softwood obtained from Wrightia tinctoria, which are then lacquered and sold. This locally-made Channapatna toys were less toxic, consumed less energy and had minimum environmental impacts as compared to readily available PVC toys [13].

Similar trends in terms of protecting and improving technology and innovations that can contribute to easier development, but also better promotion and placement of traditional products can be seen in other countries, such as China $[14,15]$. In the history of China's bright and colorful folk arts, there flash numerous art forms, including the facial makeup art and culture, the shadow play art and culture, the paper-cut art and culture, and the kite drawing art and culture, and so on. These are the unique arts only of our nation with five thousand years of the development, and there is a need to be well integrate into the current art education [16] in the study where students learn about traditional handicrafts with a whole-body interactive simulation utilizing WebAR devices is visible that the Chinese traditional handicraft learning mode based on WebAR affords embodied interaction and improves learning between real context and virtual devices. This contribution is highly relevant for users who aim to learn and be creative [17].

The example of Pakistan testify that traditional knowledge about the sustainable utilization of heritage is eroded in Pakistan among the younger generations due to rapid globalization and industrialization processes, so the appropriate strategies for revitalizing this heritage in a sustainable way should be urgently fostered [18].

In that sense there are some examples of good practice such as The Tourism Cluster "Slavonska kosarica", founded by the City of Slavonski Brod in 2011, which can be seen as an example of good practice in the networking segment. Already in 2012, the cluster became regional and today it is networking $134 \mathrm{food}$, beverage manufacturers, providers of tourist services, as well as public institutions and handicraft manufactures from the whole Slavonia region [19. ]The networking and inclusion of the handicraft manufactures is a 
strategy which enables them to be more competitive and sustainable on the international and domestic market. In the next text the results of the primary research show the role and the level of tourist valorization of the has handicrafts in the area of Dubrovnik.

\section{The results of the primary research}

\subsection{Research methodology}

For the purpose of this paper the empirical research has been conducted in Dubrovnik using method of structured interview. The interviews have been carried out in Dubrovnik The sample has consisted of 48 employees. The respondents were residents, employed by companies in Dubrovnik (mostly in ACI Marina Komolac, Dubrovnik). The aim of the research was to determine the importance and touristic valorization of local traditional crafts from local residents point of view. In $91 \%$ of cases, respondents were women and $9 \%$ were male, $48 \%$ of whom were up to 40 years of age, 40 between 41 and 60 years and $12 \%$ over 61 years. With a share of $31 \%$, respondents with a secondary qualification are represented, $28 \%$ have a high, $23 \%$ and $18 \%$ have a higher professional qualification, while $18 \%$ of respondents have a master's degree or $\mathrm{PhD}$. Descriptive statistics were used to process the data. For the purpose of this paper the secondary data referring to the cultural tourist motivation has also been used. The results of secondary research which have been carried out in 2011 in the area of Dubrovnik, has been considered together with the results of primary research regarding the elements of cultural motivation.

\subsection{Research results and discussion}

According to the results of the survey, $66 \%$ of respondents think that there is high level of interest in Konavle embroidery, $31 \%$ think it is mediocre, $3 \%$ think it is little. According to the results of the survey, $63 \%$ of respondents think that there is a high interest in Mljet embroidery, $34 \%$ consider it is mediocre, 3\% find out that it is little. The share of $69 \%$ respondents consider that there is a high interest in Coastal embroidery, 28\% think the interest is mediocre and 3\% of them think it is small. The share of $67 \%$ of respondents find out that knitting very interesting, $25 \%$ think that the interest is knitting is mediocre, $5 \%$ think it is small and 3\% consider it is not interesting for tourists. The share of $55 \%$ of respondents think that stonemasonry is very interesting, $25 \%$ think it is mediocre, $10 \%$ of respondents think it is little, and $10 \%$ think it is completely irrelevant. In terms of the importance of silk culture, $50 \%$ of respondents consider it very important, while $30 \%$ think it has middle meaning 5\% consider that it has little meaning, while $15 \%$ think it is completely irrelevant. According to the the results of the research it is visible that local residents mostly have positive attitudes towards the traditional crafts and they are aware of their role in the context of tourist product offer. Exisiting research has been targeted specifically at micro-destination ACI Marina Komolac, but it is also important and connected with touristic destination Dubrovnik and other destinations in area of Dubrovnik.

According to the results of the survey $15 \%$ of the respondents think that Konavle embroidery has high level of touristic valorization, $46 \%$ consider it is mediocre touristic valorized, $31 \%$ think the level of valorization is low and $8 \%$ consider it is not touristic valorized at all. The same situation is with Mljet emboidery and Coastal embroidery. The share of $15 \%$ of respondents think that stonemasonery has high level of touristic valorization, $39,5 \%$ think it is mediocre, $38 \%$ consider it is low and $7,5 \%$ think that the stonemasonery is not touristic valorized. The lowest level of touristic valorization has silkculture. The $62 \%$ respondents consider that it is mediocre touristic valorized, 7,5 think 
that the level of touristic valorization is high, $24 \%$ think it is low and $7,5 \%$ find out that it is not valorized at all. According to the results of the research it is visible that some of the crafts have better postion, but it can not be considered as satisfed.

The results of the research which has been carried out in area of Dubrovnik in 2011 [20] involving the sample of 335 tourists shown that the most respondents $(56.61 \%)$ have cited culture as one of the motives for visiting Dubrovnik, The share of $16.23 \%$ of tourists have cited culture as the only motive for visiting Dubrovnik. According to the results of the same survey conducted in 2011, there is a correlation (based on a hi-square test, with $95 \%$ reliability), between primary cultural motivation and cultural education and the highest number of primary cultural oriented tourists as a motive for visiting cultural attractions and events cited a desire to learn and willing to be active participant in co-creation of tourist product.

\section{Conclusion}

Based on the results obtained from the empirical research in the area of Dubrovnik, Croatia, it is also clear that traditional crafts are recognized as important element of cultural heritage. On the other side there is an unsatisfied level of involment in the touristic offer. Konavle, Mljet and Coastal embroidery have been better positioned on the international touristic market, than stonemasonry and silkculture, but there is also need to improve the position using the possibilities of networking and digitalization in future development. The development and touristic valorization should be supported by local authority. The formal and infromal training and education, such as specialist in craft markets should be included, too, It is way of developing skilled crafts sector which can increase local residents well-being and enable tourist to buy autochthonous and recognizable products/services. The recommendation is to include higher level of market segmentation, taking into the account necessity of beeing more focused on primary cultural motivated clients. They are willing to take part in co-creation of cultural product and their involvement and participation in handicrafts tourist offer could be the strategy for getting better market positon and creating products specifically designed for those customers.

\section{References}

1. Ioan-Franc, V., Istok, E. (2007). Cultural tourism and sustainable development. Romanian Journal of Economic Forecasting, 1, 89-96.

2. Wang, N. (2000). Tourism and Modernity: A Sociological Analysis. Oxford: Pergamon Press.

3. Robinson, M. (1999). Cultural Conflicts in Tourism: Inevitability and Inequality. In M. Robinson \& P. Boniface (Eds.)., Tourism and Cultural Conflicts. Wallingford: CAB International

4. Endersen, K. (1997). Sustainable Tourism and Cultural Heritage. A Review of Development Assistance and Its Potential to promote Sustainability, NWHO.

5. Wadhwa, G. (2017). Social impact through global co-creation. Proceeding of 11th international technology, education and development conference (pp. 8071-8079). Valence: IATED - International Association of Technology Education \& Development.

6. http://www.ukessay.com 
7. Sufang, Z. (2019). Education of traditional Folk Arts and Crafts and Discipline Construction of Art Design. JOSR Journal of Research \& Method in Education, 9(6), 74-76.

8. http://www.india.export.com

9. Melkani, E., Mehta, M., Gadhi, S. (2020). Drudgery Reduction and Grip Fatigue Review of Indian Women Making Handicrafts. Retrieved from: http/www. academia.edu

10. Kumar Pradhan, A. (2019). Innovation of Traditional Textile art and Crafts in North East India. International Journal of Trend in Scientific Research and Development, 3(4), 1193-1197.

11. http://www.touristplacecinindia.com

12. Rangaswamy, J., Kumar, T., Bhalla, K. (2018). A Comprehensive Life-Cycle Assessment of Locally Oriented Small-Scale Toy Industries: A Study of traditional Channapatna Toys as Against low-cost PVC (Poly-Vinyl Chloride) Toys made in China. In A. Laurent, A. Leclerc, M. Niero, Y. Dong, SI. Olsen, M. Owsianiak, N. Bey, M. Ryberg, \& MZ. Hauschild (Eds.), Proceedings of the 25th Cirp life cycle engineering (lce) conference (pp 487-492). Amsterdam: Elsevier Science.

13. Ji, R. X. (2016). Contemporary Inheritance and Innovation of Bamboo Weaving Crafts of Quxian. National Art Circles, 1, 71-75.

14. Peng, L. (2018). Living Protection and Development of Traditional Artistic Handicrafts: A Case Study from „Bamboo Weaving by Family Liu“ in Quxian County of Sichuan Province. Art and Design review, 6(3), 160-167.

15. Bai, Y. (2018). Research on the Cultivation and Molding of Female College Students' Trarditional Cultural Values by Folk Craft Teaching. In JK. Hung, Z. Liu \& Y. Pei (Eds.), Proceedings of 2018 international symposium - quality education for teenagers (pp. 135-139), Dockland: ST Plum-Blossom Press.

16. Ji, Y., Tan, P., Fills, D.I. (2019). Chinese Traditional Handicraft Education Using AR Content. Leonadro, 53(2), 199-200

17. Loncaric, B. (2018). Participation of the tourism cluster "Slavonska kosarica" in international projects - yes or no? In AM. Tonkovic \& B. Crnkovic (Eds.), 7th international scientific symposium economy of eastern Croatia - vision and growth (pp. 823-829). Osijek: Josip Juraj Strossmayer University Osijek.

18. Abdullah, Khan, S.M., Pieroni, A., ul Haq, Z., Ahmad, Z., (2020). Mazri Nannorrhops ritchiana(Griff) Aitch.): a remarkable source of manufacturing traditional handicrafts, goods and utensils in Pakistan. Journal of ethnobiology and ethnomedicine, 16(1), 45.

19. Barač, A., Dragičević, M., Letunić, S. (2012). Cultural attractions in the function of sustainable development- the case of Dubrovnik. Proceedings of the 6th International Conference Enterprise Odyssey „Corporate governance and public policy-path to sustainable future” (pp. 1331-1345). Šibenik: University of Zagreb. 